\title{
ANTISIPASI CORONA : PENYEMPROTAN DISINFEKTAN DAN PENYULUHAN PERILAKU HIDUP BERSIH DAN SEHAT (PHBS) DI MUSHOLA
}

\author{
Cyntiya Rahmawati ${ }^{1}$, Baiq Leny Nopitasari2), Alvi Kusuma Wardani²), Baiq Nurbaety ${ }^{1}$, Nur Furqani ${ }^{1}$. \\ Yuli Fitriana ${ }^{2)}$, Anna Pradiningsih 2)
}

1)Program Studi D3 Farmasi, Fakultas IImu Kesehatan, Universitas Muhammadiyah Mataram, Mataram, NTB, Indonesia
2) Program Studi S1 Farmasi, Fakultas IImu Kesehatan, Universitas Muhammadiyah Mataram, Mataram, NTB, Indonesia

Corresponding author :Cyntiya Rahmawati

E-mail :cyntiya.apt@gmail.com

Diterima 17 September 2020, Direvisi 17 November 2020, Disetujui 17 November 2020

\begin{abstract}
ABSTRAK
Coronavirus Disease (COVID-19) menjadi masalah kesehatan di dunia sebagai pandemi dan kasusnya sampai Juli 2020 terus meningkat khususnya di Indonesia termasuk di Kabupaten Lombok Timur yang merupakan kabupaten dengan total kasus terbanyak di NTB.Pengabdian ini bertujuan agar mushola yang secara rutin digunakan oleh warga di Desa Masbagik Selatan Kabupaten Lombok Timur selalu terjaga kebersihannya serta meningkatkan kesadaran masyarakat untuk menerapkan Perilaku Hidup Bersih dan Sehat (PHBS). Kegiatan ini dilaksanakan dengan penyemprotan mushola dengan disinfektan dan penyuluhan PHBS melalui spanduk dan poster. Hasil yang diharapkan adalah penyemprotan disinfektan di mushola tetap dilakukan secara rutin dan meningkatkan kesadaran masyarakat untuk tetap menerapkan PHBS di era new normal ini guna mencegah penularan Covid-19 di tempat ibadah khususnya.
\end{abstract}

Kata kunci: covid-19; disinfektan; PHBS; mushola.

\begin{abstract}
Coronavirus Disease (COVID-19) is a health problem in the world as a pandemic and the case until July 2020 continues to increase, especially in Indonesia, including in East Lombok District which is the district with the most cases in NTB. The aims are to keep the mosque that is routinely used by residents in Masbagik Selatan Village, East Lombok Regency,always to be clean and increase public awareness to implement Clean and Healthy Behavior (PHBS). This activity is carried out by spraying the mosque with disinfectants and PHBS counseling through banners and posters. The expected result is that spraying disinfectants in the mosque continues to be done routinely and increase public awareness to keep applying PHBS in this new normal era to prevent Covid-19 transmission in places of worship specifically.
\end{abstract}

Keywords: covid-19; disinfectant; PHBS; mosque

\section{PENDAHULUAN}

Awal tahun 2020, Coronavirus Disease (COVID-19) menjadi masalah kesehatan di dunia, yang diawali dengan temuan kasus kluster pneumonia dengan etiologi yang tidak jelas di Kota Wuhan, Provinsi Hubei, China. Perkembangan kasus yang begitu cepat dan jumlah kasus terus meningkat dengan penyebaran antar negara disertai dengan laporan kematian hampir di seluruh dunia termasuk di Indonesia, maka WHO menetapkan COVID-19 sebagai pandemic (Direktorat Jenderal Pencegahan dan Pengendalian Penyakit, 2020).

COVID-19 adalah penyakit jenis baru yang belum pernah diidentifikasi sebelumnya pada manusia.Tanda dan gejala umum infeksi COVID-19 adalah gangguan pernafasan akut seperti demam, batuk, sesak nafas, dan hasil rontgen menunjukan infiltrat pneumonia luas di kedua paru. Masa inkubasi rata-rata 5-6 hari dengan masa inkubasi terpanjang 14 hari. Pada kasus COVID-19 yang berat dapat menyebabkan pneumonia, sindrom pernafasan akut, gagal ginjal, bahkan kematian (Direktorat Jenderal Pencegahan dan Pengendalian Penyakit, 2020).

Sampai dengan tanggal 27 Juli 2020, dilaporkan di 192 negara total kasus konfirmasi 16.412.815 kasus dengan 652.039 kematian (CFR 3,97\%) dan 10.042.362 pasien telah sembuh, dimana Amerika Serikat, Brazil, dan India menjadi 3 negara dengan jumlah kasus Covid-19 tertinggi (Google News, 2020).Sedangkan di Indonesia dilaporkan total kasus konfirmasi 100.303 dengan 4.838 kematian (CFR 4,82\%), dan pasien sembuh sebanyak 58.173 (Badan Nasional 
Penanggulangan Bencana, 2020). Kasus COVID-19 di Indonesia tersebar di seluruh Provinsi, termasuk Provinsi Nusa Tenggara Barat (NTB). Menurut data COVID-19 di Provinsi NTB pada tanggal 27 Juli 2020, jumlah kasus terkonfirmasi sebanyak 1.946 , pasien meninggal sebanyak 110 pasien (CFR 5,65\%), dan pasien sembuh sebanyak 1.224 pasien (Pemerintah Provinsi NTB, 2020).

Virus corona merupakan virus yang memiliki selubung atau sampul (enveloped virus) dengan pelindung lapisan lemak. "Disinfektan dapat merusak lapisan lemak tersebut sehingga membuat virus corona cukup lemah dibandingkan dengan norovirus yang merupakan virus tanpa selubung dan virus lainnya yang memiliki cangkang protein yang lebih kuat", ungkap Kepala Loka Penelitian Teknologi Bersih LIPI, Ajeng Arum Sari di Bandung (Humas LIPI, 2020). Disinfektan adalah proses pengurangan jumlah kemungkinan mikroorganisme ke tingkat bahaya yang lebih rendah pada area yang terindikasi kontaminasi oleh mikroorganisme (Dinas Kesehatan Provinsi DKI Jakarta, 2020).

Berdasarkan data perkembangan kasus COVID-19 di Provinsi NTB, Kabupaten Lombok Timur merupakan kabupaten dengan total PPTG+OTG+ODP+PDP terbanyak di NTB, dengan pasien konfirmasi positif sebanyak 180 kasus, dirawat 53 pasien, pasien sembuh 119, dan pasien meninggal dunia sebanyak 8 jiwa (Pemerintah Provinsi NTB, 2020). Sehingga masyarakat di Kabupaten Lombok Timur, khususnya di Desa Masbagik Selatan, haruslah memiliki kewaspadaan yang tinggi, disertai pemahaman yang baik dan benar tentang cara pencegahan penularan COVID-19 serta aksi nyata disinfektan di fasilitas umum seperti mushola yang menjadi tempat berkumpulnya masyarakat yang berada di Desa Masbagik Selatan.

\section{METODE}

Pengabdian masyarakat ini dilaksanakan pada hari Senin, 20 Juli 2020 di mushola Kampung Karang Siswa Desa Masbagik Selatan, Kabupaten Lombok Timur. Metode yang digunakan dalam pengabdian masyarakat ini adalah penyemprotan disinfektan di mushola Kampung Karang Siswa Desa Masbagik Selatan Kabupaten Lombok Timur. Selain itu memberikan ember dan sabun cuci tangan kepada mushola untuk memudahkan warga menerapkan salah satu perilaku hidup bersih dan sehat. Pada ember tersebut ditempelkan pula poster 6 langkah cuci tangan pakai sabun dengan air mengalir. Tim juga memberikan spanduk yang berisikan edukasi cara beribadah di era new normal.

\section{HASIL DAN PEMBAHASAN \\ Kegiatan Penyemprotan Disinfektan}

Digunakan cairan disinfektan sodium hipoklorit (cairan pemutih) yang diencerkan dengan air, dengan konsentrasi yang dianjurkan sebagai disinfektan permukaan adalah $0,1 \%$ (1.000 bagian perjuta) atau alkohol dengan konsentrasi $70-90 \%$ sebagai alternatif untuk mendisinfeksi permukaan (World Health Organization, 2020)

Penyemprotan disinfektan dilakukan di dalam mushola, tempat wudhu, toilet, dan di halaman mushola. Gambar 1 merupakan salah satu kegiatan penyemprotan disinfektan di mushola.

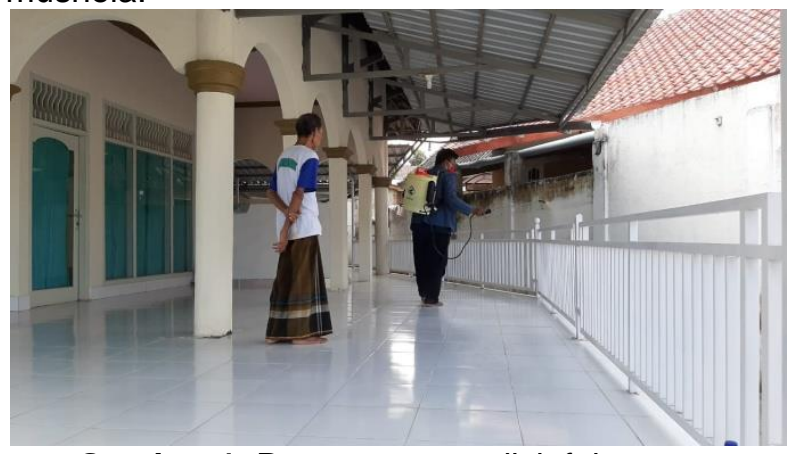

Gambar 1. Penyemprotan disinfektan (Sumber: dokumentasi pribadi)

\section{Penyuluhan Perilaku Hidup Bersih dan Sehat}

Penyuluhan Perilaku hidup bersih dan sehat melalui poster cara cuci tangan yang ditempel pada ember. Kemudian ember dan sabun cuci tangan diserahkan kepada Ketua RT agar dapat digunakan oleh warga sekitar sehingga diharapkan meningkatkan kesadaran warga untuk selalu berperilaku hidup bersih dan sehat.

Enam langkah cuci tangan pakai sabun dan air mengalir menurut Kemenkes adalah:

1. Basahi tangan, gosok sabun pada telapak tangan kemudian usap dan gosok kedua telapak tangan secara lembut dengan arah memutar.

2. Usap dan gosok juga kedua punggung tangan secara bergantian.

3. Gosok sela-sela jari tangan hingga bersih.

4. Bersihkan ujung jari secara bergantian dengan posisi saling mengunci.

5. Gosok dan putar kedua ibu jari secara bergantian.

6. Letakan ujung jari ke telapak tangan kemudian gosok perlahan. Bilas dengan air bersih dan keringkan.

Cara tersebut dilakukan selama 60 
detik dan dilakukan di 5 waktu penting, yaitu sebelum makan, setelah $B A B$, sebelum menjamah makanan, sebelum menyusui, setelah beraktivitas (Kementerian Kesehatan $\mathrm{RI}$, 2020).

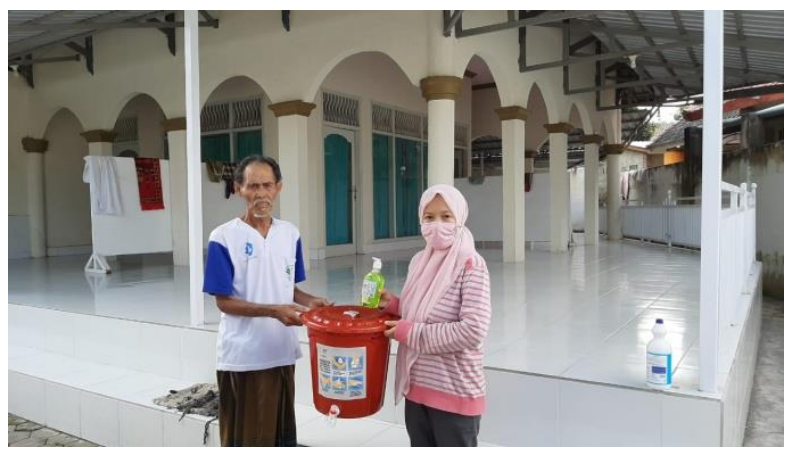

Gambar 2.Penyerahan ember dan sabun cuci tangan (Sumber: dokumentasi pribadi)

\section{Penyuluhan Cara Beribadah di Era New Normal}

Penyuluhan cara beribadah di era new normal melalui media spanduk yang akan dipasang di mushola.

Panduan Kegiatan Menjaga Kebersihan Untuk Pencegahan Penularan Covid-19 di Masjid atau Mushola dan Tempat Ibadah Lainnya (Kementerian Kesehatan RI, 2020):

1. Pastikan seluruh area Masjid atau Mushola bersih. Melakukan pembersihan dengan disinfektan (cairan pembersih) secara berkala minimal 3 kali sehari.

2. Menjaga kebersihan karpet dan alat sholat dengan cara dicuci atau menggunakan mesin vacuum cleaner secara rutin atau mengganti karpet sajadah pribadi.

3. Menyediakan sarana cuci tangan pakai sabun (CTPS) dengan air mengalir di toilet dan hand sanitizer di setiap pintu masuk, lift, dan tempat lain yang mudah diakses.

4. Menghimbau seluruh jamaah agar menggunakan Al-Qur'an dan alat sholat pribadi (mukena, sarung, sajadah, dan peci).

5. Menginformasikan kepada seluruh jamaah untuk membatasi berjabat tangan dan menjaga jarak kontak dengan orang lain yang sedang batuk/bersin.

6. Memasang pesan-pesan kesehatan di tempat-tempat strategis.

7. Menginformasikan kepada jamaah, apabila merasa tidak sehat (memiliki gejala pilek/batuk/sesak nafas) atau pernah berkunjung ke Negara terjangkit (dalam 14 hari terakhir) agar melaksanakan sholat di rumah.

8. Pengurus masjid dan mushola agar selalu memantau dan memperbarui perkembangan informasi tentang Covid-19 dengan puskesmas/Dinas Kesehatan setempat secara berkala.

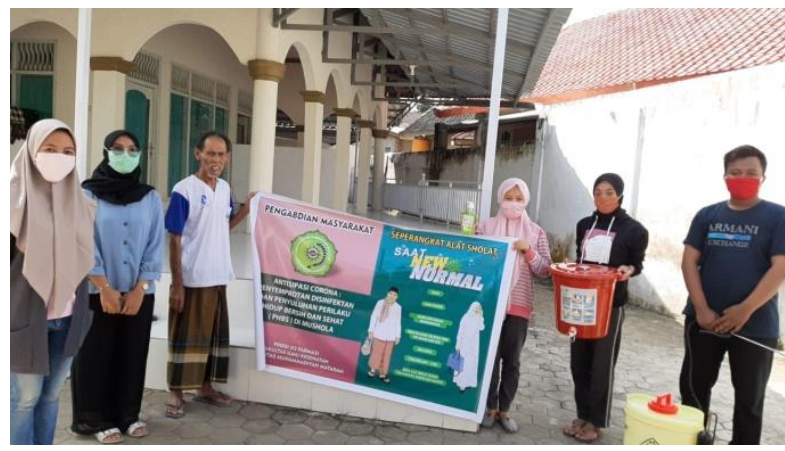

Gambar 3. Penyuluhan Cara Beribadah di Era New Normal (Sumber: dokumentasi pribadi)

\section{SIMPULAN DAN SARAN Simpulan}

Penyemprotan disinfektan disertai dengan edukasi Perilaku Hidup Bersih dan Sehat di Mushola Kampung Karang Siswa Masbagik Selatan Kabupaten Lombok Timur telah dilakukan. Diharapkan penyemprotan disinfektan di mushola tetap dilakukan secara rutin mengingat mushola tersebut tetap dipergunakan oleh warga sekitar untuk beribadah. Adanya poster new normal saat beribadah dan poster cuci tangan serta tersedianya sarana ember cuci tangan diharapkan meningkatkan kesadaran masyarakat untuk tetap menerapkan perilaku hidup bersih dan sehat di era new normal ini guna mencegah penularan Covid-19 di tempat ibadah khususnya.

\section{Saran}

Penyemprotan disinfektan dilakukan secara rutin di mushola kampung Karang Siswa Desa Masbagik Selatan. Selain itu, disarankan warga mencuci tangan dengan sabun dan membawa alat ibadah sendiri serta menggunakan masker saat beribadah ke mushola.

\section{DAFTAR RUJUKAN}

Badan Nasional Penanggulangan Bencana. (2020, Maret 30). Jumlah Kasus (COVID-19) Global dan Indonesia. Retrieved from Badan Nasional Penanggulangan Bencana: bnpb.go.id

Centers for Disease Control and Prevention. (2020, Maret 31). Coronavirus Disease 2019 (COVID-19): Cleaning and Disinfection for Households. Retrieved from Centers for Disease Control and 
Prevention:

https://www.cdc.gov/coronavirus/2019ncov/prevent-getting-sick/cleaningdisinfection.html

Dinas Kesehatan Provinsi DKI Jakarta. (2020). Pedoman Disinfeksi. Jakarta: Dinas Kesehatan Provinsi DKI Jakarta.

Direktorat Jenderal Pencegahan dan Pengendalian Penyakit. (2020). Pedoman Pencegahan Dan Pengendalian Coronavirus Disease (COVID-19) Revisi Ke-4. Jakarta: Kementerian Kesehatan Republik Indonesia.

Google News. (2020, Juli 27). Google News. Retrieved Juli 28, 2020, from Virus Corona (COVID-19): https://news.google.com/covid19/map? $\mathrm{hl}=\mathrm{id} \& \mathrm{gl}=\mathrm{ID \&}$ ceid $=\mathrm{ID}: \mathrm{id}$

Humas LIPI. (2020, Maret 23). Daftar Sementara Bahan Aktif dan Produk Rumah Tangga untuk Disinfeksi Virus Corona Penyebab COVID-19. Retrieved Mei 20, 2020, from LPTBA LIPI/ed: fz/Mar/2020

Kementerian Kesehatan RI. (2020). Flyer: 6 Langkah Cuci Tangan Pakai Sabun (CTPS). Retrieved Oktober 20, 2020, from

https://promkes.kemkes.go.id/flyer-6langkah-cuci-tangan-pakai-sabun-ctps

Kementerian Kesehatan RI. (2020). Panduan Kegiatan Menjaga Kebersihan Lingkungan dan Langkah-Langkah Disinfeksi Dalam Rangka Pencegahan Penularan Covid-19. Retrieved Oktober 20, 2020, from https://www.google.com/url?sa=t\&rct=j $\& q=\&$ esrc $=s \&$ source $=$ web $\& c d=\& c a d=r j$ a\&uact=8\&ved $=2$ ahUKEwiB4LuEv4jtA hVHWX0KHWIMD7YQFjADegQIBBAC \&url=https\%3A\%2F\%2Fcovid19.kemk es.go.id\%2Fdownload\%2FPanduan_D esinfeksi_dalam_Rangka_Pencegaha n_Penularan_Covid19.pdf\&usg=AOvV aw

Pemerintah Provinsi NTB. (2020, Juli 27). Data COVID-19. Retrieved Juli 28, 2020, from Pemerintah Provinsi NTB: corona.ntbprov.go.id

World Health Organization. (2020, Mei 15). Pembersihan dan Disinfeksi Permukaan Lingkungan Dalam Konteks Covid-19, Panduan Interim. Retrieved Oktober 20, 2020, from https://www.who.int/docs/defaultsource/searo/indonesia/covid19/pemb ersihan-dan-disinfeksi-permukaanlingkungan-dalam-konteks-covid19.pdf?sfvrsn=2842894b_2 